\title{
Commentary
}

\section{COVID-19 and the judiciary: the case for access to testing Sudhi versus Union of India}

\author{
Diya Uberoi* \\ Postdoctoral Fellow, Dalla Lana School of Public Health, University of Toronto, Toronto, Canada
}

Received: 02 July 2020

Revised: 05 August 2020

Accepted: 10 August 2020

\section{*Correspondence:}

Dr. Diya Uberoi,

E-mail: diya.uberoi@utoronto.ca

Copyright: $\odot$ the author(s), publisher and licensee Medip Academy. This is an open-access article distributed under the terms of the Creative Commons Attribution Non-Commercial License, which permits unrestricted non-commercial use, distribution, and reproduction in any medium, provided the original work is properly cited.

\section{INTRODUCTION}

The rule of law and judicial institutions are key instruments in any country's response to a health crisis. ${ }^{1}$ People's ability to access courts and claim redress for violations of rights can push states to uphold their commitment to ensure the protection of population health. Indeed, the last few decades have witnessed a rise in domestic public interest litigation, in which courts have successfully held governments responsible for their health obligations. Despite growing success, policy makers and scholars still question courts' ability to successfully uphold the right to health and achieve more equitable gains in policy. ${ }^{2-4}$

Criticisms of courts' engagement with the right to health largely concern their ability to balance competing interests and distribute limited resources. When courts engage with health, they are often seen as ignoring resource limitations. Indeed, in a number of instances, judicial engagement with health has weakened states' ability to set public health priorities. ${ }^{5}$ While such critiques identify areas for further research regarding the impact of litigation, judicial decisions need to be seen in the broader context in which they were brought. States tend to drag their feet in upholding minimum obligations, and judicial action allows for a suite of checks and balances to ensure these obligations are met, and where necessary, increased. In the current COVID-19 pandemic, for example, we simply have no choice but to increase access to testing and treatment to ensure the protection of health. If we are to contain the pandemic, we cannot overlook the role of courts as a necessary instrument for change. Using the recent COVID-19 testing decision as a case study, this commentary calls for increased trust in judicial action in the midst of a public health crisis.

\section{THE ROLE OF COURTS AND THE CASE FOR ACCESS TO TESTING}

Testing not only allows the state to identify those who may be infected, guiding the medical treatment they may need, but it informs our understanding of the pandemic and allows the state to take steps to contain any future outbreak. ${ }^{6}$ Indeed, "maximum testing has been on top of the WHO's guidelines for detecting and stopping the spread" of the coronavirus. ${ }^{7}$ Despite this, some countries' approaches to testing have lagged behind others, and several months on, testing is still not available to everyone.

A range of reasons, including timing, lack of preparedness, logistics, expertise, and complexity of obtaining and collecting materials can account for differences in testing rates. But testing and lack of access to testing have also become issues because governments have failed to take coordinated action to respond to the pandemic. The United States has the highest number of confirmed COVID-19 cases, but is still playing catch-up in terms of testing, primarily because the CDC sent out faulty tests when the virus first emerged and failed for weeks to correct the error. ${ }^{8}$ Even after the WHO declared a public health emergency of international concern, the US Food and Drug Administration maintained regulatory barriers, curtailing the testing capability of private labs.

India only began testing in March and has one of the lowest testing rates in the world. In late March, analysis 
of 72 state-run labs revealed that the government had tested 14,175 people. ${ }^{9}$ When questioned, the medical council explained its slow response on the grounds that the disease had not spread in the community. But with a population of 1.3 billion, hundreds of millions of whom are poor and living in unhygienic and crowded conditions, there is a very real fear that if testing remains too far behind the curve, a count of "confirmed" cases won't account for even the tip of the iceberg. To compound the problem, the Indian Council of Medical Research has approved only one homegrown testing kit so far, and imports are delayed because of a global surge in demand. This has made testing even more expensive, and the high costs have hindered people's ability to access testing and services when necessary. ${ }^{10}$ While government hospitals are free, they are not always easily accessible, and while the government recently allowed private labs to conduct COVID-19 tests, it fixed the price at 4,500 Rs. per test, keeping prices out of reach for not only the poor but other vulnerable populations such as women and migrants, who are struggling to make ends meet.

On 8th April, when the supreme court called on the state to make testing free and ensure more equitable access to care, some scholars lauded the judgment as a step towards containing the pandemic. ${ }^{11}$ As one author put it, "if you want to contain a pandemic, you can't have testing determined by cost". 9 Therefore, when the court modified its order a week later to make testing free for only those living below the poverty line, an obligation the state was already providing, it was seen as an affront to justice for some of the most marginalized groups in society.

Under international law, states have an obligation to ensure access to affordable testing and care for all. Health care goods, facilities, and services, including access to testing, need to be available in sufficient quantities within the state, accessible to everyone without discrimination, respectful of medical ethics, scientifically and medically appropriate, and of good quality. ${ }^{12}$

To be considered "accessible", these goods and services must be especially accessible to the most vulnerable or marginalized sections of the population; within safe physical reach and affordable for them. While the right to health is subject to progressive realization, access to treatment is a core obligation that must be provided immediately. ${ }^{12}$ High costs of treatment deter people from seeking life-saving care, which, in viral cases like the current pandemic, has serious consequences not only for individual life but the life and health of the entire community.

In times "like the present, when the ability to access services and the fair distribution of public resources can make a difference between life and death, justice institutions must be available to protect the rights of the least powerful among us". ${ }^{13}$

\section{THE SUPREME COURT DECISION OF $8^{\text {th }}$ APRIL}

In the case should be Sudhi versus Union of India, the Indian supreme court ordered the central government to prevent private hospitals from charging excessive prices for testing and to reimburse testing costs so that COVID19 tests could be free for all. ${ }^{11}$ When the government responded by capping COVID-19 testing at 4,500 Rs. (59 USD) a test, Mr. Sudhi filed a public interest suit on behalf of the 'common man', arguing that testing should be available for all given the rising rates of morbidity and mortality due to COVID-19 across the country. ${ }^{11}$ The supreme court found that a price of 4,500 Rs. for both screening and confirming tests was arbitrary and unreasonable under article 14 of the Indian constitution. The court held that when the life and health of the entire population are at risk, everyone, not only the state, has a duty to help contain the spread of the virus. In the words of the court, in this time of national calamity, "permitting private labs to charge Rs. 4500 for screening and confirming COVID-19 tests" is unreasonable when testing "may not be within the means of a large portion of the population". ${ }^{11}$ Indeed, no person should be deprived of testing because of an inability to pay. And private hospitals have an important role to play, including the extension of philanthropic services, in containing the spread of the pandemic. ${ }^{11}$

The court's decision, however, led to a backlash as private firms feared they would not be able to keep up with the pressure to produce quality tests. One week after the decision, private corporations and the state intervened and the supreme court amended its order to make testing free only for those who were covered under the National Health Policy scheme. ${ }^{14}$

The supreme court's decision in Sudhi versus Union of India brings forth the question of how best to manage resources when economies are in a slump but the life and health of the masses are at stake. Indeed, no state has unlimited resources to protect population health, but resource constraints cannot be used as an excuse to deny testing and treatment and to mask inefficiencies within a health system. Inefficiencies include not considering costeffectiveness when deciding whether to provide treatment, and arbitrary cost-setting for treatment without taking into account actual testing costs that private companies have to incur or the ability of people to afford and access such services. When such inefficiencies threaten the lives of so many, redress mechanisms need to be available to ensure accountability for the protection of health.

It is now commonplace for corporations and other nonstate actors to deliver goods such as health, education, and security, which were once governed solely through the state. ${ }^{15}$ As private entities have proliferated and begun to assume state-like functions, it has become all the more necessary to recognize that they have obligations to protect rights such as health. ${ }^{16-18}$ When non-state actors' 
obligations are recognized, it is easier to hold them accountable. As evident in the $8^{\text {th }}$ April decision, when the judiciary is able to act boldly to ensure the protection of health, we can be reminded that the duty to protect health should extend beyond the bounds of the state to include corporations and other societal actors. When HIV was at its height and high treatment costs left millions of people without care, it was only when courts began to regulate big Pharma that we saw the potential of generic manufacturing to reduce prices of anti-retroviral treatment (ARVs). ${ }^{19}$ As a consequence of such judicial decisions, private corporations have taken it upon themselves to ensure delivery of health services for those most in need during the current pandemic. For example, telemedicine has allowed physicians to continue addressing patient concerns while minimizing potential transmission of the disease. Patients can take their pulse using their smartphone and have that information sent to their digital health record all without having to set foot inside a doctor's office.

If the judiciary is able to freely uphold the right to health, we may see that they surpass our expectations in ensuring protection of that right. Indeed, over the years, the judiciary's capability in examining resource constraints while ensuring widespread change on the ground has been questioned by scholars and policy makers around the world. Some scholars argue that judicial interpretations of the right to health adopt a one-size-fitsall approach, whereby "all individuals ought to have access to any medical treatment" regardless of cost. 2 Following this reasoning, it becomes clear that such an approach can not only lead to a flood of successful rightto-health claims, but it can impose significant costs on already-strained public health systems.

In a growing number of cases, however, courts have effectively considered resources and still ensured widespread change on the ground. In fact in some of those decisions, courts have found that the state was acting unreasonably and merely hiding behind claims of resource constraints. ${ }^{20}$ In its seminal 1996 decision on the right to health, for example, the supreme court of India found that resource constraints could not be an excuse for failing to provide emergency health services. ${ }^{21}$ Of course, where the economy is struggling, effective allocation of resources becomes increasingly difficult. But the Sudhi decision suggests that where testing is crucial and health systems are primarily privately funded, courts should still be trusted to ensure the adequate protection of health.

The government of India has taken steps to accelerate access to testing, but it is questionable whether those steps are sufficient when limited government expenditure on health continues to restrict approximately $25 \%$ of the country's population from accessing health services at all. ${ }^{22}$ When considered in the context in which the suit was brought, the Sudhi decision shows that courts can and should occupy a greater role in the promotion and protection of health, especially in times of crisis.

\section{CONCLUSION}

The realization of the right to health calls on all societal actors to take steps to ensure the protection of health. In the midst of the current global health crisis where states are struggling to increase access to testing and treatment for the masses, accountability for health becomes increasingly important. In this context, we must not overlook the potential power of the judiciary when states opt to sideline widespread health protections in favor of other societal elements such as economic stability.

\section{REFERENCES}

1. United Nations Development Programme. Ensuring Access to Justice in the Context of Covid-19, May 2020. Available at: https://www.undp.org/content/ undp/en/home/librarypage/democratic-

governance/access_to_justiceandruleoflaw/ensuringaccess-to-justice-in-the-context-of-covid-19-.html.

Accessed on 9 June 2020.

2. Rumbold B, Baker R. Universal Health Coverage, Priority Setting, and the Human Right to Health. Lancet. 2017;390:10095:712-4.

3. Ferraz O. The right to health in the courts of Brazil: worsening health inequities? Health Human Rts. 2009;11:33-45.

4. Andia TS, Lamprea E. Is the judicialization of health care bad for equity? a scoping review. Int $\mathbf{J}$ Equity Health. 2019;18:61.

5. Parmet WE. Populations, public health, and the law. 2009. Washington, DC: Georgetown University Press.

6. Hellewell J, Abbot S, Gimma A. Feasibility of controlling COVID-19 outbreaks by isolation of cases and contacts. Lancet Global Health. 2020;8:488-96.

7. World Health Organization. Laboratory testing for coronavirus disease 2019 (COVID-19) in suspected human cases: interim guidance, 2020. Available at: https://apps.who.int/iris/handle/10665/331329. Accessed 10 May 2020.

8. Lopez G. Why America is still failing on Coronavirus testing, 2020. Available at: https://www.vox.com/2020/4/10/21214218/trumpcoronavirus-testing-social-distancing. Accessed on 1 May 2020.

9. Biswas S. Coronavirus: Why is India Testing so Little? 2020. Available at: https://www.bbc.com/ news/world-asia-india-51922204. Accessed on 29 April 2020.

10. Alluri A, Pathi K. India coronavirus: should people pay for their own Covid-19 tests? 2020. Available at: https://www.bbc.com/news/world-asia-india52322559. Accessed on 1 June 2020

11. Sudhi SV. Union of India and Ors 8 April 2020. Writ Petition No. 10816/220 (Supreme Court of India).

12. UN Committee on Economic, Social and Cultural Rights (CESCR). General Comment No. 14: The 
Right to the Highest Attainable Standard of Health (Art. 12 of the Covenant), 11 August 2000, E/C.12/2000/4. para. 12, para 43.

13. International Development Law Organization. Statement by the Director General of IDLO, Jan Beagle: A rule of law-based response to the Covid19 Pandemic, 2020. Available at: https://www.idlo.int/news/policystatements/statement-director-general-idlo-janbeagle-rule-law-based-response-covid-19. Accessed on 29 April 2020.

14. Sudhi SV. Union of India and Ors. April 14, 2020, Application for Intervention No. 48265/2020 (Supreme Court of India).

15. Cockayne J. Private Military and Security Companies. In: Andrew Clapham and Paola Gaeta (eds) The Oxford Handbook of International Law in Armed Conflict. 2014. New York: Oxford University Press.

16. Yildiz E. The roles and responsibilities of non-state actors: the case of education and training internet, 2016. Available at: https://www.norrag.org/theroles-and-responsibilities-of-non-state-actors-thecase-of-education-and-training/. Accessed on 1 June 2020.

17. Clapham A. Human Rights Obligations of NonState Actors. Oxford University Press; 2006.
18. Sassoli M. Involving Organized Armed Groups in the Development of the Law? in Odello $M$ and Beruto GL eds. Non-State Actors and International Humanitarian Law- Organized Armed Groups: A Challenge for the 21st Century. Milano: Franco Angeli; 2010.

19. Novartis AGV. Union of India. April 1, 2013. Civil Appeals Nos. 2706-2716 of 2013 (Supreme Court of India).

20. Ahmed MV. Union of India and Others. Delhi High Court. W.P. (C) 7279/2013. 2014 (Delhi High Court).

21. Paschim Banga Khet Mazdoor Samity V. State of West Bengal. 1996. 4 S.C.C. 37 (Supreme Court of India).

22. National Sample Survey Organization. National sample survey, $60^{\text {th }}$ round, 2005. New Delhi: Ministry of Statistics and Programme Implementation.

Cite this article as: Uberoi D. COVID-19 and the judiciary: the case for access to testing Sudhi versus Union of India. Int J Community Med Public Health 2020;7:3769-72. 